Abstracta Iranica Abstracta Iranica

Revue bibliographique pour le domaine irano-aryen

Volume 25 | 2004

Comptes rendus des publications de 2002

\title{
« Le cinquième livre du Dēnkard ». Transcription, traduction et commentaire, St. Ir., 23 (2000).
}

\section{Rédaction}

\section{(2) OpenEdition}

1 Journals

\section{Édition électronique}

URL : http://journals.openedition.org/abstractairanica/4773

DOI : 10.4000/abstractairanica.4773

ISSN : 1961-960X

Éditeur :

CNRS (UMR 7528 Mondes iraniens et indiens), Éditions de l'IFRI

\section{Édition imprimée}

Date de publication : 15 mai 2004

ISSN : 0240-8910

Référence électronique

Rédaction, « « Le cinquième livre du Dēnkard ». Transcription, traduction et commentaire, St. Ir., 23 (2000). », Abstracta Iranica [En ligne], Volume 25 | 2004, document 211, mis en ligne le 15 mars 2006, consulté le 25 septembre 2020. URL : http://journals.openedition.org/abstractairanica/4773; DOI : https://doi.org/10.4000/abstractairanica.4773

Ce document a été généré automatiquement le 25 septembre 2020.

Tous droits réservés 


\title{
« Le cinquième livre du Dēnkard ». Transcription, traduction et commentaire, St. Ir., 23 (2000).
}

\author{
Rédaction
}

1 L'ouvrage est dédié à la mémoire de Jean de Menasce qui fut le maître des deux auteurs.

2 Le Dēnkard est une somme théologique rédigée au $9^{\mathrm{e}} \mathrm{s}$. par des compilateurs utilisant des données anciennes d'époque sassanide ( $3^{\mathrm{e}}-7^{\mathrm{e}}$ siècles). Il est composé de neuf livres dont les deux premiers sont perdus. Le troisième a été traduit en français par Jean de Menasce (Paris, Klincksieck, 1973), et le sixième en anglais par Shaul Shaked (Boulder, Westview, 1979). Le cinquième livre est ici publié pour la première fois, en édition critique, par J. Amouzgar et Ahmad Tafazzoli. Ce dernier ayant tragiquement disparu en 1997, sa collaboratrice a dû achever seule le travail. Moins philosophique que le livre III, le livre $\mathrm{V}$ est néanmoins très riche en enseignements sur la cosmologie mazdéenne, les légendes sur Zoroastre, l'eschatologie, le rituel et les lois de pureté, etc... Il se présente sous la forme littéraire des questions et réponses.

Dans le présent ouvrage, un avant-propos, une bibliographie et une introduction précèdent le texte lui-même en transcription, avec apparat critique. Viennent ensuite la traduction française, le commentaire et enfin, un glossaire qui contient tous les mots du texte en transcription, puis en translittération suivie de la traduction française.

\section{INDEX}

Thèmes : 6.1. Zoroastrisme 


\section{AUTEURS}

\section{RÉDACTION}

Directeur de la revue et secrétariats (Paris et Téhéran) 